\title{
IMPLEMENTATION IMPACT OF THE TRIPLECHEM LEARNING MODEL ON PERSONAL AND SOCIAL ATTITUDES OF CHEMISTRY PROSPECTIVE TEACHERS
}

\author{
I Wayan Suja1 ${ }^{*}$, , Leny Yuanita², Muslimin Ibrahim ${ }^{3}$ \\ ${ }^{1}$ Chemistry Education Departement, Universitas Pendidikan Ganesha, Singaraja \\ ${ }^{2}$ Science Education Study Program, Program Pascasarjana Universitas Negeri Surabaya \\ ${ }^{3}$ Science Education Study Program, Program Pascasarjana Universitas Negeri Surabaya
}

\begin{abstract}
Abstrak
This study was aimed at describing and explaining the impact of the application of TripleChem learning model to the personal and social attitude of chemistry prospective teacher. The study was conducted in three classes of Organic Chemistry I at the Chemistry Education Department of Universitas Pendidikan Ganesha in the odd semester of the 2015/2016 academic year. Each class consists of 22 students. In each class, learning is done by applying the TripleChem learning model. The data were collected by two observers using the observation sheet. Data analysis was performed descriptively. The results indicate that the personal and social attitudes of prospective teachers have increased gradually until it reaches the optimum condition around the eight meeting. The findings suggest that the TripleCem learning model is effectively implemented to train the personal and social attitudes of chemistry prospective
\end{abstract}

Keywords:

TripleChem learning model, personal attitude, social attitude, prospective

\section{INTRODUCTION}

Generally, people see the teacher as a profession with duties teaching and educating, which is no different from office workers. The term teacher as a trusted and imitated person as introduced by Ki Hajar Dewantara, has forgotten, especially there are many cases show unscrupulous teachers are not worthy to emulate. To restore the position of the teacher as a profession that should be trusted and emulated, from the beginning of entering academic world of education, students should be trained to behave as a prospective teacher (Hendri, 2010)

As a prospective teacher, an educational student should have been introduced to the Four of Teacher's Competency. Later they are required not only to master professional competence and pedagogic but also to have personality competence and social. They are required to have a holistic intelligence, with characteristics: faith, morals, knowledgeable, and skilled; so it is natural to have a respectable profession as a teacher (Suja, 2014; Rasmita \& Bertha, 2010).

Teacher's personality competencies include at least faithfulness and cautious, noble, wise, honest, sportive, and able to be role models for learners and society; democratic, steady, stable, mature, authoritative, objectively, and able to evaluate its own performance. Furthermore, social competence is related to the ability to communicate and interact effectively and efficiently with others (Government regulations Number 74 of 2008).

Although both competencies must be possessed by a teacher, in reality during his / her academic education (S1), students have never been specially trained in the development of their personal and social attitudes. Theoretically, the four teachers competencies will be introduced intensively in the level of professional education, while in academic education is only seen as nurturant effects of a learning process.

Given that primary and secondary education has made spiritual and social competence as the core competencies in every learning field, this study is packed with effective spheres as a measurable instructional impact in Organic Chemistry learning by applying the TripleChem learning model. During classroom learning students are trained to develop their personal attitudes, including honest, meticulous, diligent, responsible, and maintaining the health and hygiene of the environment. Furthermore, social attitudes developed include the ability to ask questions, contribute ideas, accept opinions of others, 
communicate the results of observation and discussion, and work together (Nur, 2011, Undiksha, 2013 and Permenristekdikti RI No. 44 Year 2015).

The purpose of this study is to describe and explain the impact of the application of TripleChem learning model to the personal and social attitudes of prospective teachers. The results of this study can be utilized by educators as information materials in training and measuring personal and social attitudes of students in learning field of study. That conditions need to be done considering education is a process of culture and empowerment of learners to achieve educational goals in accordance with the level of the educational unit.

\section{METHOD}

The research was conducted in three classes of Organic Chemistry I at Chemistry Education Department of Universitas Pendidikan Ganesha in the odd semester of academic year 2015/2016. Each class consists of 22 students. In each class, learning is done by applying the TripleChem learning model, with the syntax and target of prospective teachers attitude development can be seen in Table 1.

\section{Table 1. The Syntax and Development Target of Prospective Teachers' Attitude}

\begin{tabular}{cll}
\hline No. & Syntax & Development Target \\
\hline 1. & Observing Step & Asking questions that support the investigation. \\
a. Planning an investigation & The accuracy of observing the investigation \\
b. Conducting an investigation & variables. \\
& Recording data honestly in the observation table. \\
& Diligence to carry out investigations to obtain the \\
& expected data. \\
& Willingness and ability to work together. \\
& Maintain the safety and cleanliness of the \\
& environment. \\
\hline
\end{tabular}

2. $\quad$ Reasoning Step

(Analyze the data and formulate the conclusion of the investigation)

\section{Modeling Step}

(Designing molecular structures using molymod models)

4. Explanation Step

(Communicate the results of the investigation)
Contributing ideas.

Open accept opinions of others.

Willingness and ability to work together.

Contributing ideas.

Willingness and ability to work together.

Communicating the results of the investigation responsibly.

Asking question.

Open accept opinions of others.

The data were collected by two observers using the student performance assessment rubric, which had been validated by five experts (expert team) through Focus Discussion Group (FGD) activity, and it was declared worthy to be used for data retrieval. Assessment is done by scoring on a scale of 1 - 4 (score 1 = less, 2 = enough, 3 = good, and $4=$ excellent), in accordance with the criteria set in each assessment item. Data analysis was conducted descriptively based on criteria: average $3.5-4.0$ (very good), $2.5-3.4$ (good), 1.5 - 2.4 (enough), and 1.0 - 1.4 (less)

\section{RESULTS AND DISCUSSION}

The implementation of the TripleChem learning model has an impact on student attitudes, which include personal and social attitudes. The personal and social attitudes of class A, B, and C students are measured through observation using student attitude scoring rubric. The measurement data is shown in Table 2 . 
Tabel 2. Recap of The Students' Attitude Data

\begin{tabular}{|c|c|c|c|c|c|c|c|c|c|c|c|c|}
\hline \multirow{2}{*}{ No } & \multirow{2}{*}{ Attitude } & \multirow{2}{*}{ Cls } & \multicolumn{10}{|c|}{ Average Scores of the Meeting to } \\
\hline & & & 1 & 2 & 3 & 4 & 5 & 6 & 7 & 8 & 9 & 10 \\
\hline $\mathbf{A}$ & Personal Attitude & & & & & & & & & & & \\
\hline \multirow[t]{3}{*}{1.} & Honestyto reports the & A & 4.00 & 4.00 & 4.00 & 4.00 & 4.00 & 4.00 & 4.00 & 4.00 & 4.00 & 4.00 \\
\hline & results of the investigation & $\mathrm{B}$ & 4.00 & 4.00 & 4.00 & 4.00 & 4.00 & 4.00 & 4.00 & 4.00 & 4.00 & 4.00 \\
\hline & & $\mathrm{C}$ & 4.00 & 4.00 & 4.00 & 4.00 & 4.00 & 4.00 & 4.00 & 4.00 & 4.00 & 4.00 \\
\hline \multirow[t]{3}{*}{2.} & uracy of observing & A & 3.41 & 3.59 & 3.64 & 3.73 & 3.77 & 3.82 & 3.86 & 3.91 & 3.91 & 3.91 \\
\hline & stigation variables & B & 3.45 & 3.55 & 3.64 & 3.68 & 3.73 & 3.77 & 3.82 & 3.91 & 3.91 & 3.91 \\
\hline & & $\mathrm{C}$ & 3.41 & 3.50 & 3.68 & 3.64 & 3.73 & 3.82 & 3.86 & 3.91 & 3.91 & 3.91 \\
\hline \multirow[t]{3}{*}{3.} & ence conducts an & A & 3.50 & 3.50 & 3.55 & 3.59 & 3.64 & 3.68 & 3.77 & 3.82 & 3.82 & 3.82 \\
\hline & gation until it obtains & B & 3.50 & 3.50 & 3.55 & 3.64 & 3.73 & 3.77 & 3.82 & 3.86 & 3.86 & 3.86 \\
\hline & the expected data. & $\mathrm{C}$ & 3.55 & 3.55 & 3.59 & 3.68 & 3.68 & 3.73 & 3.86 & 3.86 & 3.86 & 3.86 \\
\hline \multirow[t]{3}{*}{4.} & Carrying out the task & $\mathrm{A}$ & 3.18 & 3.32 & 3.41 & 3.45 & 3.55 & 3.59 & 3.68 & 3.77 & 3.77 & 3.77 \\
\hline & responsibly & $\mathrm{B}$ & 3.18 & 3.36 & 3.36 & 3.45 & 3.59 & 3.64 & 3.68 & 3.68 & 3.68 & 3.68 \\
\hline & & $\mathrm{C}$ & 3.23 & 3.18 & 3.18 & 3.32 & 3.45 & 3.50 & 3.73 & 3.77 & 3.77 & 3.77 \\
\hline \multirow[t]{6}{*}{5.} & Maintaining the safety and & A & 2.82 & 3.05 & 3.14 & 3.23 & 3.36 & 3.50 & 3.55 & 3.59 & 3.64 & 3.64 \\
\hline & cleanliness of the & $\mathrm{B}$ & 2.82 & 2.95 & 3.18 & 3.27 & 3.41 & 3.45 & 3.50 & 3.77 & 3.77 & 3.77 \\
\hline & environment & $\mathrm{C}$ & 2.77 & 2.91 & 3.27 & 3.23 & 3.27 & 3.45 & 3.55 & 3.55 & 3.55 & 3.55 \\
\hline & Average personal attitude & $\mathbf{A}$ & 3.38 & 3.49 & 3.55 & 3.60 & 3.66 & 3.72 & 3.77 & 3.82 & 3.83 & 3.83 \\
\hline & & B & 3.39 & 3.47 & 3.55 & 3.61 & 3.69 & 3.73 & 3.76 & 3.85 & 3.85 & 3.85 \\
\hline & & C & 3.39 & 3.43 & 3.55 & 3.57 & 3.63 & 3.70 & 3.80 & 3.82 & 3.82 & 3.82 \\
\hline
\end{tabular}

Tabel 2 (Continued)

\begin{tabular}{|c|c|c|c|c|c|c|c|c|c|c|c|}
\hline \multirow{2}{*}{\multicolumn{2}{|c|}{ No Attitude }} & \multirow{2}{*}{ Cls } & \multicolumn{9}{|c|}{ Average Scores of the Meeting to } \\
\hline & & & 1 & 2 & 3 & 4 & 5 & 6 & 7 & 8 & 10 \\
\hline
\end{tabular}

B. Social Attitude

1. Questioning skills that support inquiry

2. Abilities to express ideas

\begin{tabular}{lllllllllll} 
A & 2.73 & 2.86 & 3.05 & 3.18 & 3.41 & 3.50 & 3.59 & 3.77 & 3.77 & 3.77 \\
B & 2.73 & 2.82 & 2.91 & 2.91 & 2.91 & 3.18 & 3.64 & 3.82 & 3.86 & 3.86 \\
C & 2.68 & 2.86 & 2.91 & 2.95 & 3.00 & 3.27 & 3.77 & 3.82 & 3.86 & 3.86 \\
A & 2.68 & 2.73 & 2.82 & 2.91 & 3.00 & 3.18 & 3.50 & 3.64 & 3.64 & 3.64 \\
B & 2.64 & 2.91 & 3.05 & 3.09 & 3.14 & 3.14 & 3.23 & 3.23 & 3.23 & 3.23 \\
C & 2.59 & 2.82 & 2.82 & 3.14 & 3.18 & 3.18 & 3.32 & 3.36 & 3.36 & 3.36 \\
A & 2.77 & 2.86 & 2.91 & 3.05 & 3.23 & 3.32 & 3.55 & 3.59 & 3.64 & 3.64 \\
B & 2.77 & 2.82 & 2.86 & 3.23 & 3.55 & 3.59 & 3.64 & 3.64 & 3.64 & 3.64 \\
C & 2.82 & 2.95 & 3.00 & 3.00 & 3.41 & 3.41 & 3.73 & 3.73 & 3.73 & 3.73 \\
A & 3.23 & 3.32 & 3.41 & 3.45 & 3.55 & 3.59 & 3.68 & 3.77 & 3.77 & 3.77 \\
B & 3.18 & 3.36 & 3.36 & 3.45 & 3.59 & 3.64 & 3.68 & 3.68 & 3.68 & 3.68 \\
C & 3.18 & 3.18 & 3.18 & 3.32 & 3.45 & 3.50 & 3.73 & 3.77 & 3.77 & 3.77 \\
A & 3.59 & 3.64 & 3.68 & 3.73 & 3.77 & 3.77 & 3.82 & 3.86 & 3.86 & 3.86 \\
B & 3.55 & 3.55 & 3.68 & 3.68 & 3.73 & 3.73 & 3.77 & 3.82 & 3.82 & 3.82 \\
C & 3.64 & 3.59 & 3.64 & 3.64 & 3.68 & 3.77 & 3.82 & 3.82 & 3.82 & 3.82 \\
A & $\mathbf{2 , 9 8}$ & $\mathbf{3 , 0 8}$ & $\mathbf{3 , 1 7}$ & $\mathbf{3 , 2 6}$ & $\mathbf{3 , 3 9}$ & $\mathbf{3 , 4 7}$ & $\mathbf{3 , 6 3}$ & $\mathbf{3 , 7 3}$ & $\mathbf{3 , 7 4}$ & $\mathbf{3 , 7 4}$ \\
B & $\mathbf{2 , 9 7}$ & $\mathbf{3 , 0 9}$ & $\mathbf{3 , 1 7}$ & $\mathbf{3 , 2 7}$ & $\mathbf{3 , 3 8}$ & $\mathbf{3 , 4 5}$ & $\mathbf{3 , 5 9}$ & $\mathbf{3 , 6 4}$ & $\mathbf{3 , 6 5}$ & $\mathbf{3 , 6 5}$ \\
C & $\mathbf{2 , 9 8}$ & $\mathbf{3 , 0 8}$ & $\mathbf{3 , 1 1}$ & $\mathbf{3 , 2 1}$ & $\mathbf{3 , 3 5}$ & $\mathbf{3 , 4 3}$ & $\mathbf{3 , 6 7}$ & $\mathbf{3 , 7 0}$ & $\mathbf{3 , 7 1}$ & $\mathbf{3 , 7 1}$ \\
\hline
\end{tabular}

Description of scoring scores: 4 = very good, $3=$ good, $2=$ enough, and $1=$ less.

The data in Table 2 shows students' personal attitudes as follows. First, honesty in reporting the results of the investigation is the best personal attitude during learning. Assessment is based on consideration, that the student reports what he/she observed, not what he/she expected. Second, the personal attitude of students in maintaining the safety and cleanliness of the environment is the lowest. Third, other personal attitudes (rigor, perseverance, and responsibility) have been classified well since the first meeting and gradually increased until it reaches excellent optimum conditions around the eighth meeting. 
The tendency of the students' personal attitudes during the learning from the first to the tenth meeting is shown in Figure 1.

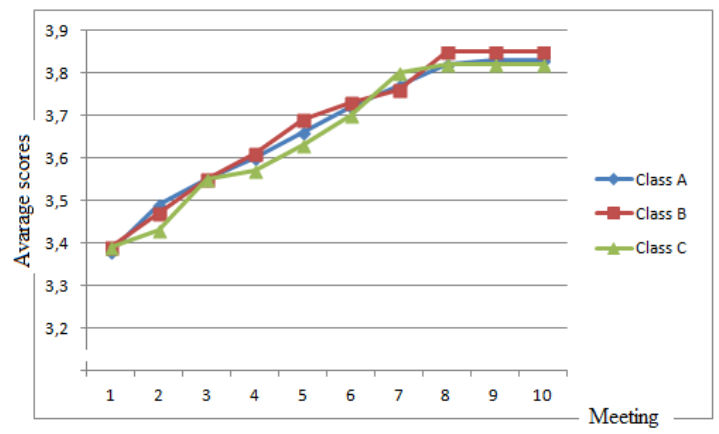

Figure 1.

Students' Personal Attitudes

Student social attitude can be described as follows. First, the students' skill in putting forward the idea is the lowest. Second, the students' ability to work together during the lesson shows the highest score and gradually increases until it reaches the optimum condition from the eighth meeting. Third, the students' skills in making questions and their openness to accept the opinions of others at the initial meetings are lower than their ability to communicate the results of the investigation. The three types of social skills gradually increase during learning process until reaching the optimum conditions.

The tendency of students' social attitudes in class A, B, and C is shown in Figure 2. The graph of students' social attitudes in Figure 2 shows students' social attitudes gradually increasing and reaching optimum conditions from the eighth meeting.

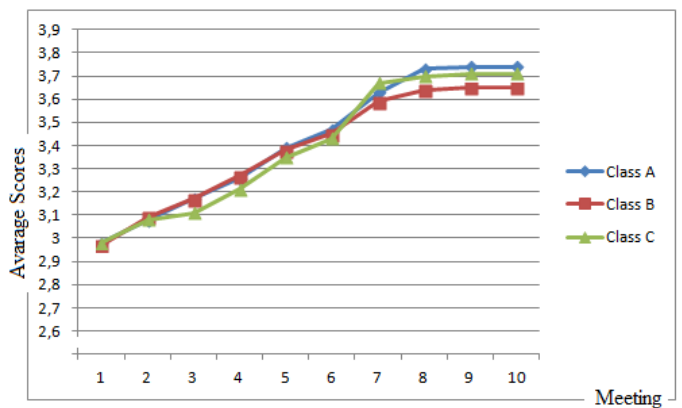

Figure 2.

Students' Social Attitudes

This research data shows students' personal and social attitude at the beginning of learning is classified good and then increase gradually until reaching very good category. Those conditions show the TripleChem learning model can be used to develop the personal and social competence of prospective teachers. The development of the prospective teacher's personal and social attitudes, according to the National Research Council (1996) should be done continuously from the student to the end of his professional career as a teacher.

This opinion is relevant with Mundilarto's view (2013), that personal and social attitudinal education should be done gradually, from the recognition of value at the cognitive stage, understanding and valuing effectively, forming a conative commitment, and ending with practice in the form of concrete action. The four stages by Ki Hajar Dewantara formulated with the words "cipta, rasa, karsa, and karya," as the inherent potential of human beings as human resources. This potential will develop if there is a deliberate effort to cultivate it through the educational process. 
Five personal attitudes developed through learning by applying the TripleChem model, include: honest, meticulous, diligent, responsible, and maintain the safety and cleanliness of the environment. These five personal attitudes are also included in the values of characters that must be familiarized by the students, including prospective teachers (Nasir, 2013). The results of this study indicate students' honesty in reporting observation results is the best compared to the other four attitudes. If it can still be maintained and developed, these findings provide hope that one day will be able to produce a trustworthy teacher (Asmani, 2012).

Honesty became the first and foremost personal attitude in this research. According to Asmani (2012), honesty is a behavior based on the effort to make oneself as a person who can always be trusted. It can be manifested in words and actions, both to oneself and to others. According to Suja (2015), honesty is the most basic and necessary humanitarian code of ethics to support the world (Atharva Veda XII 1.1). Because of the importance of honesty for maintain harmony with oneself and the environment, the honest behavior is seen as the most important religious teaching. The value of honesty is the basis for developing a person's mental attitude and faith indicators (Puja, 1984). In the context of academic society life, honesty is often seen as more important than truth. Learners, including students, may be wrong (not true), but do not try to lie (dishonest).

Accuracy deals with precision in making observations or investigations. The more precisely the data obtained with the actual data on the observed object the higher the accuracy. In terms of measurement, the closer the actual price (the smaller the deviation) the higher the measurement precision. This study shows students' ability to observe research variables at the macroscopic level after the first meeting is very high

Diligently relates to intrinsic motivation in accomplishing specific tasks. Suja (2015) stated that in Balinese society, diligent or tenacious is related to "brata", which can be interpreted as a certain discipline to achieve the goal. By citing various mantras in the Vedas, Titib (1996) states, that perseverance must be based on self-control, which will ultimately lead to success in achieving goals. On that basis, perseverance usually becomes one package with success.

Although it has been classified well at the beginning of the study and is increasing steadily until very well at the end of the study, the student's responsibility in performing the task is judged to be ranked fourth. Responsibility is seen as the attitude and behavior of a person to perform the obligations, as he should do to himself, society, environment, state, and God (Asmani, 2012). In Balinese society, responsibility is aligned with "swadharma", which includes the meaning of obligations that must be carried out with full awareness, without external coercion (Suja, 2015). Thus, responsibility must be done spontaneously and do not procrastinate.

Maintaining environmental health and hygiene as a form of the caring attitude towards the environment is an act that always tries to prevent environmental damage (Asmani, 2012). The attitude is considered the lowest in the students who became subjects in this study. Students are still quite often neglected in maintaining the cleanliness of the environment and the safety of self and others. The condition shows that students still need to practice a lot to maintain the harmonious relationship with nature and social environment, as a form of embodiment of Tri Hita Karana philosophy on Balinese society (Suja, 2015).

The five social attitudes developed in this study include the willingness and ability to ask questions, contribute ideas, accept the opinions of others, communicate the results of investigations, and work together. The willingness to work together is most pronounced among the five student social attitudes. The data shows the students have the ability to live in society, but still have constraints in the affairs of scientific communication orally. Conditions that occur because of communication skills need to exercise longer, and students who made the subject of research is a student of the third semester, so still lack experience in scientific communication. The argument is consistent with the view of Pitafi \& Farooq (2012), which states the ability to communicate is complex, and need to exercise intensively in interaction with the environment.

Lack of students' ability to communicate has been reported by the Working Group on Soft Skills Development of Undiksha Students (2013). The working groups considered the need for guidance and the development of the skills of students to communicate orally, express ideas, and argue abilities. Lack of communication ability is also felt by the alumni of top universities in Indonesia. The result of tracer study on alumni of Gadjah Mada University (UGM) shows that the oldest university graduate in Indonesia still feels less in communication ability (Rahayu, 2005). 
The implementation of the TripleChem learning model emphasizes the skill of asking and raising ideas. The emphasis on both types of communication skills because at the beginning of learning there is a tendency of students not to ask if not forced, and not give a view if not appointed. Both types of skills are indicators of students' thinking activities and provide an overview of students' difficulties in building their mental models. Given the importance of questioning activities in learning, Brodjonegoro (2016) called the questioning activity not only improve the quality of the learning process, but will also contribute positively to the nation's progress in science and technology.

\section{CONCLUSIONS AND SUGGESTIONS}

Based on the results of research and discussion can be drawn conclusion that the implementation of TripleChem learning model can improve the personal and social attitude of chemistry prospective teachers. The students' personal and social attitudes increased gradually to the optimum conditions around the eighth meeting.

Relevant to the conclusions and problems encountered during the learning process, suggestions can be given as follows. First, the campus should create and maintain a humanist, democratic, and honest academic atmosphere. Secondly, learning must make the prospective teacher a man who longs for compassion and be able to work together, because only the teacher who has compassion and be able to compromise with himself who be able to educate the students later.

\section{REFRENCE}

Asmani, J. M. (2012). Character education internalization handbook at school. Jogjakarta: Diva Press.

Brodjonegoro, S. S. (2016). The role of MIPA and MIPA education is innovative and charged with local wisdom in strengthening national identity and competitiveness. Proceedings of the Mathematic and Sciences Nasinal Seminar, Denpasar July 30, 2016

Chusnani, D. (2013). Character education through science. Journal of Policy and Education Development, 1 (1): 9 - 13.

Elfindri, Rumengan, J., Wello, M. B., Tobing, P., Yanti, F., Eriyani, E., \& Indra, R. (2010). Soft skills for educators. Tk.: Baduose Media

Hendri, E. (2010). Qualified teachers: professional and intelligent emotions. Journal Saung Guru, 1(2), 1 11

Mundilarto. (2013). Building character through science learning. Character Education Journal, 3 (2): 153163.

Nashir, H. (2013). Character education based on religion and culture. Yogyakarta: Multi Presindo

National Research Council (NRC). (1996). National science education standards. Washington DC: National Academic Press.

Nur, M. (2011). Modules of science process skills. Surabaya: Center for School Science and Mathematics Surabaya State University.

Pendit, S. (1995). Bhagavadgita. Jakarta: Hanuman Sakti.

Regulation of the Minister of Research, Technology and Higher Education of the Republic of Indonesia Number 44 Year 2015 on National Standards of Higher Education

Government Regulation No. 74/2008 on Teachers.

Working Group of Student Soft Skills Development (2013). Development of soft skills of Undiksha students through multi level role model based on trikaya parisudha. Singaraja: Universitas Pendidikan Ganesha

Pudja, G., 1984. Sraddha. Jakarta: Mayasari.

Rahayu, G. R. (ed). 2005. Student Centered Learning. Yogyakarta: Gajah Mada University Educational 


\section{Development Center}

Decree of Directorate General of Higher Education of Ministry of National Education no. 44 / DIKTI / Kep / 2006 concerning the Rules of the Implementation of Group of Social Welfare Classes in Higher Education

Suja, I. W. (2014). The use of analogy in chemistry learning. Jurnal Pendidikan Indonesia, 3(2), 397 - 410.

Suja, I. W. (2015). The integration of character education into the basic natural science curriculum. In the National Seminar of FMIPA Undiksha V (pp. 131-136). Singaraja

Tilaar, H. A. R. (2011). Character education and people-driven dimensions: A critical pedagogical review. Paper presented at National Seminar on Character Based and People-Driven Education theme at Undiksha Singaraja, May 7, 2011.

Undiksha. (2013). Guidance study of undergraduate and diploma programs of Faculty of Mathematics and Natural Sciences. Singaraja: Universitas Pendidikan Ganesha 